\title{
Socio-Racial Sensibilities towards coloured subaltern sectors in the Spanish Atlantic
}

\author{
Alejandro E. Gómez \\ Maître de conferences Université Lille 3, 3 Rue du Barreau, 59650 Villeneuve-d'Ascq, France \\ e-mail: alejandroegomez@gmail.com
}

Submitted: 2 January 2015. Accepted: 28 February 2015

\begin{abstract}
This article studies from a longue durée perspective the articulation of anti-slavery sentiments and other socio-racial sensibilities within the Spanish Atlantic, from the first theological criticisms of the $16^{\text {th }}$ century to the efforts to abolish slavery in Cuba, Puerto Rico and Spain, in the second half of the $19^{\text {th }}$ century. We focus on the most significant cases of individuals who shared a white identity and who advocated against slavery, slave trade and socio-racial discrimination of Free Coloureds. We argue that the many egalitarian proposals made during the Spanish American revolutions and at the Cortes of Cádiz represent a second golden moment (after the 'Mulatto Affaire' during the French Revolution) in the struggle for the granting of political equality to subaltern sectors the Atlantic World. In the end, we expect to provide a clearer picture of how the socio-racial sensibilities contributed to accelerate, or to postpone, the introduction of abolitionist or equalitarian measures vis-à-vis the coloured subaltern sectors in the Spanish Atlantic in the Late Modern Age.
\end{abstract}

KEYWORDS: Abolitionism; slavery; citizenship; race; revolutions; liberalism; emotions; Atlantic World.

Citation / Cómo citar este artículo: Gómez, Alejandro E. (2015). "Socio-Racial Sensibilities towards coloured subaltern sectors in the Spanish Atlantic”. Culture \& History Digital Journal, 4 (2): e011. doi: http://dx.doi.org/10.3989/chdj.2015.011

RESUMEN: Sensibilidades socio-raciales en el Atlántico Hispano. Posturas anti-esclavistas, empatías ideológicas y actitudes temerosas hacia los sectores subalternos de color en España e Hispanoamérica a fines de la edad moderna.- Este artículo estudia desde una perspectiva de longue durée la articulación de los sentimientos anti-esclavistas con otras sensibilidades socio-raciales en el Atlántico español, desde las primeras críticas teológicas del siglo XVI hasta los esfuerzos para abolir la esclavitud en Cuba, Puerto Rico y España, en la segunda mitad del siglo XIx. El estudio se centra en los casos más significativos de individuos que compartían una identidad blanca y que abogaron contra la esclavitud, la trata de esclavos y la discriminación socio-racial de los libres de color. El mismo sostiene que las muchas propuestas igualitarias hechas durante las revoluciones hispanoamericanas y en las Cortes de Cádiz representan un segundo momento dorado (después del llamado 'Asunto de los mulatos' durante la Revolución Francesa) en la lucha por el otorgamiento de igualdad política a los sectores subalternos en el Mundo Atlántico. Al final, se aspira proporcionar una imagen más clara de cómo las sensibilidades socio-raciales contribuyeron a acelerar, o posponer, la introducción de medidas abolicionistas e igualitarias para los sectores subalternos de color en el Atlántico español a fines de la Edad Moderna.

PALABRAS CLAVE: Abolicionismo; esclavitud; ciudadanía; raza; revoluciones; liberalismo; emociones; Mundo Atlántico.

Copyright: (C) 2015 CSIC This is an open-access article distributed under the terms of the Creative Commons AttributionNon Commercial (by-nc) Spain 3.0 License. 


\section{INTRODUCTION}

It is currently accepted that modern abolitionism was an Euro-American phenomenon resulting from the conjunction of several factors, most particularly the libertarian sequels of the American Revolution, the underlying anti-slavery sentiments based mainly upon Christian morality, and - although at times in contradictory ways - the enlightened ideas associated with the principle of universal citizenship, mostly in France. Altogether, they permitted a sort of moral awakening and the emergence of a new political consciousness, affecting people's sensibilities and, consequently, also their standpoints towards slavery and the slave trade on both sides of the Atlantic (Brown, 2006; Davis, 1988; Ehrard, 1995; Wanquet, 1998). Another product of this shift was the defence that many abolitionists carried out on behalf of the descendants of the emancipated slaves, in addition, or separately, to their activities for the suppression of slavery and the slave trade. When we consider that the Free Coloureds were also victims of slavery for the discrimination they were subjected to, due to the "stigma" that they inherited from their African and Slave ancestry, it is not surprising that some abolitionists took on their defence.

This advocacy took place mostly in France and its Caribbean colonies after the outbreak of the Revolution in 1789 when some anti-slavery advocates, like JacquesPierre Brissot and Abbé Grégoire, began to enthusiastically support the Free Coloureds in their struggle for equal citizenship. Their efforts fostered a series of debates known historiographically as the Mulatto Affaire (Affaire des mulâtres). After some setbacks, the affair ended when the Legislative Assembly approved a decree that finally granted citizenship to Free Coloureds in March 1792 (Bénot, 1988: 57-88; Gómez, 2005a). In the British Atlantic, only the famed abolitionist Thomas Clarkson showed an interest in the Free Coloureds' cause by supporting the uprising lead by the mulatto Vincent Ogé in Saint-Domingue in 1790 (John D. Garrigus, 2011: 56).

However, it is in the Spanish Atlantic where most of the advocates of the Free Coloureds' cause can be found, after France. We can identify them from the discussions that took place at the Cortes gathered at Cádiz between 1810 and 1814 , and also in many of the revolutions that broke out in Spanish America during the same period. Curiously enough, the historiography of abolitionism commonly considers Hispanic anti-slavery advocates in the first stages of the Age of Revolution, unlike their British and French counterparts, as isolated figures. This viewpoint is mainly based upon the fact, as asserted by Robin Blackburn (1988: 395), that the former did not organize actual abolitionist movements until the $1820 \mathrm{~s}$, while the latter began in the last third of the eighteenth century. Furthermore, if compared to the collective character of the abolitionist movements in the northern Atlantic and Brazil, there were not true abolitionist societies in the Spanish Atlantic until the second half of the $19^{\text {th }}$ century.
The subject of abolitionism in the Spanish Atlantic has been mostly studied for the cases of Cuba, Puerto Rico and Spain. Their entwinements had been largely researched by several historians (Arroyo Jiménez, 1982; Corwin, 1967; Díaz Soler, 1970; Mascaraque, 1988; Morales Carrión, 1986; Murray, 2002; Schmidt-Nowara, 1999; Scott, 1985; Solano and Guimerá Ravina, 1990; Vilar, 2006, 1986, 1977). The cases in continental Spanish America have remained somewhat overlooked by this historiography, which has mainly focused the discussions on the abolitionist proposals made at the Cortes of Cádiz (1810-1814) and during the so-called Liberal Triennium (1820-1823) (Berquist, 2010; Moreno García, 2003). There is however a large scholarly production within the different national historiographies and from foreign scholars on the abolitions of slavery in most HispanicAmerican nations. Nevertheless, the only study available aiming to cover all those processes in a single work is $L a$ abolición de la esclavitud en América Latina by Hebé Clementi (1974). This work studies the case of each country separately without giving much detail about the Atlantic connections or the motivations of those who advocated against slavery. This is understandable considering that, on the one hand, by the time it was published, 1974, there was still a lack of interest in applying transnational analytical perspectives in the field of Latin American History; and that, on the other hand, subjects related to abolitionism were more largely covered by historians working on the Spanish American revolutions.

For these historians, anti-slavery sentiments and other socio-racial sensibilities were not considered a subject of interest for themselves, but rather constituent parts of the socio-liberal ideas of the political elites who ruled the newborn Hispanic-American nations. This perspective began to change in recent years given the epistemological turn experienced by the historiography of the SpanishAmerican revolutions in view of the application of 'from below' or 'subaltern' analytical perspectives. The works on Antioquia, Chile, Caracas, Cartagena, New Spain and Buenos Aires have revealed a more complex picture by showing, among other lesser known aspects, that many white-Creole political actors manifestly showed similar socio-racial sensibilities to those which gave birth to abolitionism and pro-mulatto sentiments elsewhere in the northern Atlantic World. Something similar could be asserted regarding the awareness and concerns they developed regarding the "dangerous" effects of immediate emancipation and of radical republicanism (Chaves, 2011; Contreras Cruces, 2011; Di Meglio, 2006; Gómez, 2008; Guardino, 1996; Helg, 2004; Lasso, 2007; Múnera, 1998).

Accordingly, this article intends to broaden the transnational approach regarding Atlantic abolitionism opened up by Blackburn, and continued in recent years by historians such as Seymour Drescher and Schimidt-Nowara (Drescher, 2009; Schmidt-Nowara, 2011). The aim is not only to further open up the scale of analysis, both from chronological and spatial perspectives, but also to consider anti-slavery sentiments as part of a wider framework of 
socio-racial sensibilities. The term "sensibility" (id est, perception of or responsiveness toward something) is commonly associated to the Histoire des sensibilités, which uses it mainly as variable for the historical study of senses, feelings and emotions. Despite its analytical potential, that notion has seldom been used beyond the boundaries of culture or applied in other fields of historical research, including Political History and the History of the Ideas. Bearing this in mind, the present article proposes to study the socio-racial sensibilities of individuals of Spanish or White/Whitened identity within the Spanish Atlantic, by combining conventional ideological and factual analysis, with that of sentiments and emotions.

We will focus our attention on three main aspects: Firstly, on the anti-slavery sentiments aiming to show, from a longue durée perspective, how the moral and ideological shift mentioned above began to take shape within the Spanish Atlantic, long before the outbreak of the Spanish Monarchical crisis of 1808 (which, following the guerrerista paradigm, ${ }^{1}$ has been traditionally considered as the starting point of the Spanish American revolutions) and then to explore how it evolved up to the efforts to abolish slavery in Cuba, Puerto Rico and Spain, in the second half of the $19^{\text {th }}$ century. Secondly, on the ideological empathies towards the subaltern sectors of the Americas. Here we intend to briefly outline the most significant cases of individuals or factions who advocated against slavery and socio-racial discrimination, not only of Free Coloureds or Pardos but also of other racially "different" subaltern sectors including the Indians, the many-coloured Castas and the local plebeians. ${ }^{2}$ And thirdly, on the fearsome attitudes of certain Spanish liberals and Spanish American revolutionaries. The goal here would be mainly, though not exclusively, to explore how the emotional climate resulting from certain concerns associated to the subaltern sectors and the revolutionary period, affected the sentiments and ideas of our social actors.

In the end, we expect that this threefold analytical approach will provide a clearer picture of the development and evolution of socio-racial sensibilities, and of how these contributed to accelerate, or to postpone, the introduction of abolitionist or equalitarian measures vis-à-vis the coloured subaltern sectors in the Spanish Atlantic in the Late Modern Age.

\section{ANTI-SLAVERY SENTIMENTS}

It is possible to identify antislavery sentiments since very early in the modern age. In the Spanish Atlantic, we find some Catholic priests who raised their voices against Black slavery and the African slave trade. Among them stands out the theological criticisms of Soto, Mercado and Albornoz, as well as Las Casas' regret on his recommendation to supplant Indians with African labourers in the sixteenth century; then towards the end of the following century in Cuba and the mainland, the strenuous but fruitless efforts of the Capuchin priests Francisco de Jaca and Epifanio de Moirans; and finally, by the mid- $18^{\text {th }}$ century, the intellectual condemnations expressed in the writ- ings of some Jesuits from New Spain, such as Francisco Xavier Alegre (Gallego, 2005; Kerson, 1995; López García, 1982). Nevertheless, as happened everywhere else in the Atlantic World, it was not until the outset of what Blackburn (1988: 63) defines as the 'Age of Abolition', that the existence of that servile institution and of slave trade began to be seriously questioned. In the Spanish Atlantic, this can be first observed in a parliamentary context in the years around the discussions at the Cortes of Cádiz, summoned in 1810 to design a new and more liberal constitution for the kingdoms of Spain.

Scholarly production on the subject normally focuses on the case of José Miguel Guridi y Alcocer, the representative from New Spain, and of Agustín Domingo Argüelles, the representative from Asturias. They each proposed, but did not achieve, a bill for the gradual abolition of slavery in the Spanish Empire, including the slave trade to the Spanish colonies in the Americas (Corwin, 1967: 22-23). It seems that Argüelles was heavily influenced by British abolitionism as can be evidenced in his presence at the Parliament in London during the last debates that led to the abolition of the slave trade in 1807, and also by the way in which he praised in his interventions Wilberforce's courage and supported the British parliament's prohibition of that human commerce (Diario de las discusiones y actas de las cortes, IV, 1811: 444). Later on, after the instauration of a new liberal regime in 1820 , he received a letter from Wilberforce encouraging him to continue the struggle to put an end to the trade in the Spanish domains (Wilberforce, 1841: 242-243).

There were, however, other similar though lesser known cases of Spaniards and Hispanic-Americans who struggled for those same objectives. They all formed part of the liberal circles that took shape on both sides of the Atlantic following the Napoleonic occupation of the Iberian Peninsula in 1808. Among these was the case of the Quito-born Antonio Villavicencio, who, in November 1809 , called on the Junta Central in Seville for the suppression of the slave trade and the approval of a freewomb law, which he resumed in a manuscript entitled Comentario sobre la ley de esclavos. ${ }^{3}$ There is also the case of Isidoro Antillón, who was the Aragón representative from the Liberal Party at the Cortes of Cádiz. A few years earlier, in 1802, he delivered a speech in Madrid in which he displayed a great awareness of abolitionist ideas and activities elsewhere. For example, he refers to the consequences of the French abolition of 1794 in the Caribbean and to the works of the renowned abolitionists Clarkson, Grégoire and Brissot. His liberal collaborators published his speech in Cádiz in 1811, with the aim of bolstering support for the abolitionist petitions under consideration within the Cortes (Berquist, 2010: 181ss). One such collaborator was the liberal leader and poet, Manuel José Quintana, who had invited Antillón to join him as co-editor of the liberal paper, Semanario Patriótico. Also in 1811, Quintana proposed to the Cortes a twofold motion, firstly for the abolition of slavery and secondly for slaves to have a representative in that assembly (Dérozier, 1978: 641-643). 
Amongst Quintana's liberal acquaintances was the reverend José María Blanco White, a former Catholic priest who converted to Anglicanism. He was one of the co-editors of Semanario Patriótico until he moved to London in 1810; after which, he became a promoter of socio-political liberalism in both Spain and Spanish America. He published several political imprints with the aim of encouraging politicians in those territories to introduce liberal reforms, including the abolition of slavery and the granting of citizenship to Free Coloureds. Perhaps the most influential of his works was a periodical entitled El Español, published until 1814, which often presented arguments in favour of those causes. During this time, in Britain, Blanco White also became a close collaborator of The African Institution. In 1814, in reaction to a petition from this organization, he wrote and published a text condemning the slave trade, entitled Bosquejo del Comercio de Esclavos. This work was very much influenced by Wilberforce's Letter on the Abolition of Slave Trade of 1807, which he had translated into Spanish (Almeida, 2011: 111-115; Pons, 1997; SchmidtNowara, 2013: 160).

Other individuals also struggled for the same causes as early as 1780 . In that year, in the remote governorship of Chile, two Frenchmen conceived a conspiracy aimed at overthrowing the colonial government and establishing a republic, following the example of the United States. The plan also intended to allow the indigenous peoples (Araucanos and Mapuches) to have political representatives and to abolish slavery. Eventually, the plan was disclosed and the conspirators were arrested and sent to be judged in Lima. ${ }^{4}$ In the 1790 s, several French Antillean-inspired rebellions - or rumoured rebellionswere reported throughout Spanish America, from Cuba to Rio de la Plata. These insurrections, when they actually took place, were carried out by slaves or Free Coloureds. The only exception occurred in the province of Caracas in 1797. On June that year, a Jacobin-inspired conspiracy was unveiled in the coastal city of La Guaira. It was led by the Majorcan, Juan Bautista Picornell, who had been sent from Spain to be imprisoned in that city a few months earlier, along with many of his companions, for having led a similar plot in Madrid in 1795. The conspirators' plan was to establish a republic in Venezuela, following the model the French-republican agents had implemented on the island of Guadeloupe and the regions they controlled in Saint-Domingue, where slavery had been abolished and Free Coloureds enjoyed the same political rights as Whites. The most radical measures proposed by those revolutionaries are described in the Ordenanzas, one of Picornell's political works. According to this text, once they had ousted the colonial government, they intended to ban socio-racial distinctions and to declare 'the abolition of slavery as opposite to humanity'. In this and other political documents and revolutionary songs, they set out their intention to create a multiracial brotherhood of new citizens: 'the Whites, the Blacks, the Indians and the Mulattoes' (Cf. Grases, 1997: 173-178).
After 1810, many of the newly autonomous or independent governments that emerged throughout Spanish America decided to suppress the slave trade, to free the slaves belonging to immigrating Spaniards and even to free all slaves who thereafter were brought onto their soils. They took these measures either for philanthropic reasons or as a means, in the case of the slave trade, by which to gain the support of Britain, who had prohibited it since 1807. In some cases, the Hispanic-American revolutionaries even aimed for the gradual abolition of slavery, as they did in Chile, Buenos Aires and Antioquia, where free-womb laws were approved in 1811, 1813 and 1814 respectively. These measures continued in the following decade in Uruguay (1825), Greater Colombia (1821), Mexico (1824) and, after the arrival of the southern patriotic army of San Martín, also in formerly royalist Lima (1821). Although these measures were often accompanied by philanthropic declarations of universal equality among men, they reflected, as has been stressed by many historians, more practical objectives: either to encourage slaves to join the republican armies in order to satisfy the constant need for soldiers, or to counter the recruitment of slaves by the royalist forces, or to reward their performances after the wars were over. These emancipations for military ends were also made in a less formal way, as in the Banda Oriental (today's Uruguay) by José Rondeau (commander of an army dispatched from Buenos Aires) and by the gaucho leader, José Gervasio Artigas, who even recruited fugitive slaves from neighbouring Brazil. A similar strategy was applied in Alto Peru (today's Bolivia) and Misiones, but regarding the Indians. In 1811, Juan José Castelli and Manuel Belgrano, following the secret instructions that the Junta of Buenos Aires had given aiming to stir up the 'indiada', they instituted a series of egalitarian reforms including the abolition of Indian serfdom (Goldman, 2009: 19-20; Halperín Donghi, 1972: 264-265; Seghesso De López, 2010: 20).

These recruiting practices continued even after independence had been achieved, as can be seen in the emancipations during the civil wars that broke out in Peru, the Argentinean Confederation and Paraguay in the mid-19 $9^{\text {th }}$ century. There is also the case of the War of the Triple Alliance (1864-1870), the bloodiest conflict in Latin American history, during which thousands of slaves were conscripted and incorporated into the pardo battalions of the Paraguayan army (Boidin, 2006: 349; Toral, 2007: 420423). These conscriptions gave a final blow to an already weak servile institution, permitting its suppression during those conflicts (as in Uruguay) or shortly after (as in Argentina, Peru and Paraguay). In these cases, as well as in those of Colombia, Ecuador, Peru and Venezuela, definitive suppressions of slavery were undertaken as part of the conflicts between liberals and conservatives and were not due to the action of sensitive abolitionists aiming to put an end to the slaves' ordeal (Andrews, 2004: 67, 115116, 1980; Blanchard, 2008: 3, 40-43; Lombardi, 1971: 140-141).

This does not mean a lack of anti-slavery sentiments, as can be seen in the attitudes of some of the politicians 
who supported the adoption of the measure. In Peru, Santiago Távara, who was one of the jurists who prepared the abolition bill of 1855 , published that very year a short book in support of the measure: La abolición de la esclavitud en el Perú (Távara, 1855). It recounts the evolution of the question since the free-womb decree issued by San Martín at his arrival to Peru in 1821, and analyses the way the measure was implemented and the 'lesser temporary evils' it generated in other regions of the Americas, especially Jamaica. There is also the case of the Venezuelan, José Silverio González, who in 1848 unsuccessfully proposed a congressional bill to abolish slavery. He was also decorated by the British government for having impeded the enslavement of a free black woman from the West Indies by the local authorities in 1853 (Guédez and Mendoza, 2000).

The offers of freedom during military conflicts were generally conditional on the enrolment of the slaves in the republican armies, at times stated in very threatening terms. In August 1814, the Army Commander-in-Chief of Chile, José Miguel Carrera, formed a regiment of slaves he called Ingenuos de la Patria. In order to fill its ranks, the legislators threatened those slaves who refused with a hundred lashes, three years imprisonment and perpetual slavery (Contreras Cruces, 2011). Likewise, in a decree of June 1816 on his arrival in Venezuela, the white-Creole military leader, Simon Bolivar, coming from Haiti (where he had promised mulatto president, Alexandre Petion, that he would abolish slavery), warned slaves who would not join his forces that he would not only keep them forever in bondage, but also their children aged less than fourteen years, their wives and their parents (Bolívar, 1939: 149). He would acknowledge shortly afterwards to his friend and commander in New Grenada, Francisco de Paula Santander, that offering freedom to slaves responded to the need to gain 'faithful partisans'. From this perspective, as indicated by Peter Blanchard, 'abolition seemed to be a means to an end, not an end in itself', an assertion which could be equally valid for other revolutionaries who had previously made similar proposals in the French Caribbean (Andrews, 2004: 67; Blanchard, 2008: 3, 66, 73, 88).

Indeed, in 1793, the conventionalist commissionaires in Saint-Domingue, Polverel and Sonthonax, made public a decree offering freedom to those slaves who would like to join the armies of the French Republic. This proposal was interpreted by the slaves in rebellion as a declaration of general emancipation, which led the commissionaires to change it into an immediate abolitionist decree shortly afterwards. This measure was ratified by the National Convention in Paris in February 1794. In the same year, in Guadeloupe, another conventionalist commissioner, Victor Hugues, applied a similar measure which helped him to reinforce his army and thus expel the British from the island. Later on, Hugues made public a series of announcements letting the former slaves know that, to become citizens, they had either to join the republican forces or remain working in the plantations. This particularly coercive form of emancipation, which formed part of a larger doctrine called 'republican racism' by Laurent Dubois (2004), aimed to safeguard the economy of the island. This doctrine highly influenced the conspiracy of La Guaira in 1797, as can be seen in a clause of the aforementioned Ordenanzas, which states that slaves who would not take arms, had to remain working in the haciendas. ${ }^{5}$

In other regions of Spanish America, after the inception of the independence struggles, we find other abolitionist proposals which had a more immediate effect. In New Spain, from the outset of the popular rebellion that started in 1810, these proposals were made by the main leaders, priests Miguel Hidalgo (Herreión Peredo, 2011) and José María Morelos, whose objectives were to put a stop to slavery and discrimination against the Indians and Castas. There is also the case of the town of Mompox (in north-eastern New Grenada) where, the same year, some white masters freed their slaves to show their commitment to independence (Brading, 1984: 41-42; Guardino, 1996: 66ss; Hamnett, 1986: 144; Helg, 2004: 140; Vincent, 1994). But, generally speaking, once independence from Spain was achieved, the continuation or the suppression of slavery would depend -following John Lynch (1973) — on the local economic or demographic features of each territory. Thus, where there were few slaves, for example in Chile, Mexico and Central America, slavery was abolished shortly after independence in the 1820s; whereas in territories such as Argentina, Colombia, Peru and Venezuela, whose economies still depended to some extent on that servile institution, slavery remained active until the 1850s.

During the first years of the republican period, the political leaders who advocated against slavery did so for multiple reasons. Some considered that servile institution to be contrary to the liberal principles that shaped the new-born republics, as in the case of Bolivar in Greater Colombia. In Mexico, President Vicente Guerrero (a mixed-blood and formerly "guerrilla" leader of the faction of Morelos) had slavery abolished by means of an edict in 1829 . He took this decision not only motivated by the equalitarian doctrine practiced by his faction from the outset of the independence struggles, but also aiming to discourage white immigration from the United States to Texas (Vincent, 2001: 152). Other anti-slavery advocates had acted in a seemingly more sensitive way, aiming to put an end to the slaves' ordeal and to open to them the doors of citizenship. This seems to be the case of former patriot leader, José Miguel Infante, in Chile and some members of the congress of Central America (among whom stands out the figure of the priest José Simeón Cañas), who enthusiastically proposed immediate emancipation, at times against strong pro-slavery interests. Their efforts paid off as slavery was abolished in both territories in 1823 and 1824 respectively (Clementi, 1974: 112; Duran and Contreras, 1962: 229-232; Feliú Cruz, 1973: 60ss).

A similar commitment to the abolition of slavery, only more gradual, can be found in some of those who proposed freedom of womb bills and manumission boards, 
like Manuel de Salas in Chile in 1811 (Feliú Cruz, 1973: 38-41), teacher José Félix Restrepo in Antioquia in 1814 and José de San Martín after his arrival to Peru in 1821. It took even longer for Paraguay to bring in any gradual process to end slavery, due to the long dictatorship of José Gaspar Rodríguez de Francia. After his death in 1840 , the new consulate government headed by reformist Carlos Antonio López immediately freed the dictators' slaves, and two years later, using 'paternalist' arguments, but also under British pressure, had the congress approve a free-womb law which also included the prohibition of slave trade (Cooney, 1974: 152; Martínez, 1999). In Peru, where the elites were convinced that increasing the slave population would reconstruct their economy after the wars of independence, the anti-slavery cause suffered a series of setbacks. They even tried to formally re-establish the slave trade in the 1840 s. It was a period which coincides with a sort of liberal awakening, which, as it has been asserted by Blanchard, permitted more active forms of anti-slavery agency. Liberal politicians, government officials and representatives began condemning the slave trade, whilst certain slave-owners deliberately emancipated their slaves. Among these, it is worth mentioning the case of the slave-owner and deputy from Trujillo, Alfonso González Pinillos, who emancipated the 136 he had in 1852 . Some liberal journals also radicalized their postures against slavery. One of them, El Comercio, published a translation of Uncle Tom's Cabin, which its editors dedicated to Pinillos' 'fine fruitful example' (Blanchard, 1992). The publisher of this liberal journal also printed three years later Tavara's aforementioned work on slavery.

The situation was much more different in the case of Cuba, not only due to the fact that it remained, along with Puerto Rico, under Spanish rule, but also because the island was on its way to becoming a plantation colony. This meant that the number and proportion of slaves was much higher than in any other Hispanic territory in the Americas. Francisco de Arango (the main promoter of a plantation economy for Cuba) had foreseen this "problem" from the late $18^{\text {th }}$ century and proposed, as a solution, to increase white immigration. As the percentage of Blacks rose, so did the 'fear of Africanization' on the part of white-Creoles, a situation that would affect their postures towards slavery and the slave trade. At the Cortes gathered in Spain during the Liberal Triennium, the representative from Asturias, the Count of Toreno, made a proposal to appoint a commission to enact the agreement signed with Great Britain in 1817, and which intended to put an end to the slave trade by 1820 . In the same assembly, the Cuban representative, the priest Félix Varela, wrote a plea for the gradual abolition of slavery on his island. Regretfully for them, the assembly was dismissed before their proposals could be enacted (Corwin, 1967: 37; Moreno García, 2003: 160-166).

Although Varela's project remained unpublished until the end of the $19^{\text {th }}$ century (Piqueras Arenas, 2007: 46), his ideas inspired a new generation of Cuban intellectuals like José Antonio Saco and Domingo del Monte. The lat- ter bought the liberty of a mulatto slave named Juan Francisco Manzano and encouraged him to write his autobiography. Del Monte then handed the text to the British consul and abolitionist, Richard Madden, who had it published in London in 1840. Notwithstanding this seeming sensitivity vis-à-vis the slaves' ordeal, and the fact that they were all against the continuation of the slave trade into their island, these intellectuals (including Father Varela) were not abolitionists but rather reformists concerned about the augmentation of the coloured population and they even shared - as it is clear in the case of their most notorious representative, José Antonio Saco- the racist spirit of the age (Naranjo Orovio and García González, 1996; Tornero, 2005). One of the few individuals, if not the only, who showed strong anti-slavery sentiments during this period in Cuba was Joaquín de Agüero. This young white revolutionary believed that the planters should assume their responsibility for the sufferings imposed on slaves, on which belief, in 1843, he emancipated the few he had (Ghorbal, 2009: 56; Paquette, 1988; Schmidt-Nowara, 1999).

In the late $1860 \mathrm{~s}$, the suppression of slavery in the United States and the downfall of the southern confederacy, made clear that the days of slavery were counted. On both sides of the Spanish Atlantic, liberal reformists began considering gradualist proposals mostly aiming to avoid causing any damage to the economy, but also for philanthropic reasons. This influenced on the formation of the Junta de Información sobre Ultramar (a committee gathered to propose liberal reforms for the colonies) in 1865, and led to the suppression of slave trade to Cuba by the Spanish Cortes in 1867. In Puerto Rico, where slaves were far less numerous than in Cuba and where the colonial regime had been more repressive visà-vis the reformists' intentions, abolitionism acquired a more radical aspect at times even entwined with separatism. The most radical were Segundo Ruíz Belvis and Ramón Emeterio Betances who created a secret society to free the newborn slaves and to help runaways. The latter's writings against slavery were very much inspired by the ideas of many radical abolitionists such as Victor Schœlcher, who he knew personally and who sympathise with his revolutionary plans (Mathews, 1971). During his exile in New York, Betances made public a proclamation entitled the Diez Mandamientos de los Hombres Libres, being the first commandment the abolition of slavery. He also contributed to the creation of a committee which led to a separatist insurrection (the Grito de Lares) in September 1868, whose first decree was to set free the slaves who would take up arms for the revolution.

There was another abolitionist tendency loyal to the mother country, represented by individuals like Julian Acosta, Román Baldorioty, Luís Padial and his cousin Julio Vizcarrondo. They had all favoured since at least the 1850 s the formation of a free labour market. Their struggles shifted to the metropolis in the following decade where Vizcarrondo created the Spanish Abolitionist Society and, with the support of Cuban abolitionist 
Rafael María Labra, the journal El Abolicionista Español (Morales Carrión, 1986; Schmidt-Nowara, 1999: 135137). In 1867, they convened with the Comité Français d'Émancipation and the Committee of the British and Foreign Anti-Slavery Society to organize an international anti-slavery conference. It was held in Paris, where Vizcarrondo met American abolitionist William Lloyd Garrison and probably also French abolitionist Victor Schœlcher. ${ }^{6}$ Labra also established ties with Brazilian abolitionist Joaquim Nabuco, with whom he exchanged anti-slavery propaganda. He also recommended him to leading abolitionists in the United Kingdom and France, including "a great abolitionist from Puerto Rico" living at the time in Paris. This was no other than Betances, who had become the delegate of the Provisional Government of the Cuban Republic in France. On January 23, 1881, the Spanish Abolitionist Society in a formal sitting declared Nabuco honorary member (Alonso, 2010: 5570; Domingo Acebrón, 2006: 65-66).

Whilst the insurrection failed in Puerto Rico, in Cuba, where a similar separatist insurrection had broken out also in 1868 (Grito de Yara), the struggle continued for another decade as thousands of slaves joined the rebel forces, either voluntarily or by force. As it had happened half a century earlier in continental Spanish America, this measure responded to a great extent to the need to reinforce the rebel army. Nevertheless, following Ada Ferrer, there was a genuine "desire" among the white leaders to eventually grant freedom to the slaves through gradual and indemnified abolition, once they had overthrown the colonial government. In the meantime, they shared the need to condition emancipation by military service and coercive labour (Ferrer, 1999: 22-23).

The abolitionists from the Spanish Antilles were not in favour of colonial emancipation, but rather of farreaching political reforms permitting the instauration of autonomic governments in the colonies (Acebrón, 1998: 157-158). They counted on the support of a new generation of liberal politicians in the metropolis, who took power after the Glorious Revolution of September 1868. Many of these metropolitan politicians did not only join the abolitionist society, they also became enthusiastic anti-slavery advocates. Among them the minister Segismundo Moret, who was the author of a freedom of womb law in 1870 . Nevertheless, as had happened before in continental Spanish America during the independence struggles of the first third of the $19^{\text {th }}$ century, the so-called Moret Law also aimed to calm down - as has been underlined by Rebecca Scott - the aspirations of the many slaves that were joining the rebel side after the outbreak of the Ten Years' War in Cuba in 1868. Towards the end of the following decade, several journalists, liberal politicians and other individuals began to form underground groups in Cuba, aiming for the instauration of a free labour system, and then to oppose the imposition of a transitional status for slaves (patronato) approved by the Cortes in 1880 (Corwin, 1967; Schmidt-Nowara, 1999: 126ss; Scott, 1985: 65, 136137).

\section{IDEOLOGICAL EMPATHIES}

In the Spanish Atlantic, as previously indicated, the Free Coloured's right to citizenship and other forms of modern political equality for subaltern sectors were first undertaken by conspiracies in Chile and La Guaira in 1780 and 1797 respectively. These issues were also discussed by some of the "forerunners" of the Spanish American revolutions, as well as during the Cortes gathered in Cádiz in 1810, especially in the debates regarding the representation of the American colonies. During the first sessions of these debates, some representatives from the Americas proposed that proportional representation be granted to the entire population of the colonies, including to Indians, Free Coloureds and other Castas. Whereas some American delegates supported the proposal as a means of increasing the political representation of the colonial elites, others did so for more altruistic reasons. Among the latter were the above-mentioned representatives Antillón and Quintana, who promoted the proposal outside and inside the assembly, and also of the representative Guridi y Alcocer, who passionately refuted the allegations suggesting that a measure of this sort would trigger another Haitian-like revolution in Spanish America (Diario de las discusiones y actas de las cortes, III, 1811: 91-92).

It is worth pointing out that the Cortes gathered at Cádiz in 1810 were formed mostly of liberal politicians. This led to the approval of many radical reforms: it abolished seigniorial institutions, the Indian tribute, the mita in the Andes, personal service in Spain, the Inquisition, and it increased the State's control over the Catholic Church. Nevertheless, despite the enthusiastic support shown by some representatives, none of the equalitarian proposals regarding the subaltern sectors in Spanish America were approved straightforwardly. This was mainly due to the opposition they faced both from other American representatives, because of their socio-racial prejudices, and from the majority of metropolitan representatives who feared that they would lose their political hegemony within the Cortes. Eventually, the concerns about an imperial collapse after the outbreak of the wars in different parts of Spanish America forced the representatives to grant full citizenship to Indians and Mestizos. However, Free Coloureds, because they were considered to be descendants of pagan foreigners, were only offered naturalisation certificates if they complied with certain stringent material and immaterial conditions, as established in the constitution sanctioned in 1812 (King, 1953: 39-40; Rieu-Millán, 1990: 146-151).

While this was occurring in Cadiz, in Spanish America many of the revolutionary processes underway brought in similar and even more radical legislations. Almost everywhere, white-Creole politicians were convinced that the notions of citizenship they were conceiving for the autonomous or independent regimes that had been created from 1810 onwards, had to cover the subaltern sectors. This feature of Creole republicanism was shared by both the most conservative politicians, as a means to gaining 
their support to maintain control in the territories, and the most radical revolutionaries who, motivated by philanthropic reasons, were very keen on establishing universal equality regardless of the socio-racial background of the new citizens. Consequently, almost everywhere, white revolutionaries increased the political participation of low-class whites, Indians, Mestizos, Free Coloureds and other Castas. In some places, these were even granted the right to become constituents or to have representatives in the town halls or cabildos as happened with the mulattoes of Central America in cities like Granada, Tegucigalpa and San Salvador (Dym, 2006: 91-92), in the new autonomous assemblies or even in the new national congresses. In the Captaincy General of Venezuela, in cities and towns like Barcelona, Barinas, Cumaná, Trujillo and Caracas, as indicated in their respective legislations, the autonomous assemblies chose to include within their ranks either pardo representatives or white-Creoles appointed to represent them.?

At times, these socio-racial reforms were attained in spite of the lack of support, or even the opposition, of more conservative white sectors. Following Marixa Lasso (2013), it was the active collaboration between members of the subaltern groups and the most radical white-Creoles that succeeded in including the former among the active citizens in places like Caracas, Cartagena, Mexico and Buenos Aires. This collaboration was not, however, a guarantee of success, as shown in the failed conspiracy of La Guaira in 1797 and in another plot disclosed at Havana in 1810 -we will return on this later. The promises and measures of political equality announced or implemented during the early stages of the revolutions, in general succeeded on gaining the support of the local subaltern sectors. This included their militias who, in certain places, played a key role in the unfolding of the revolutions. For instance, in August 1810, at Quito, some Free Coloureds, along with other local plebeians, participated in the attempt to liberate some members of the autonomist assembly dissolved by the royalist authorities. This rescue attempt resulted in a massacre carried out by some garrisons dispatched from Lima (Llano, 1992: 91). In Caracas, the Pardo Militia had fiercely opposed the first attempt by the white elite to establish an autonomous assembly in November 1808 . Two years later, we find the same militiamen supporting a more plural movement of white-Creoles who successfully ousted the governor and established an autonomous government (Thibaud, 2003: 48-53).

At Santiago de Chile, the Free Coloureds counted on the support - either for practical or altruistic reasonsof some important white-Creole politicians, like Manuel de Salas (who was also the author of the free-womb decree) and the president, José Miguel Carrera. The new government allowed their militia to have a commander of their own and allowed him to use the distinctive title of Don. By that time, the Cabildo of Santiago had summoned the citizens for the election of a national congress without expressively establishing socio-racial distinctions. This permitted the Pardo Militia captain, Cipriano Varas, to be elected and appear among the signatories of the Reglamento Constitucional passed in 1812. After the outbreak of the war of independence, the autonomous government decided to rename the Pardo Militia Battalion as Infantes de la Patria, in consideration of their military performances and considering that "the true distinction between citizens, should only regard their merits and virtuosities' (Contreras Cruces, 2011: 68; León, 2002).

Between 1808 and 1810, in the cities of Acapulco and Havana, several members of the local Pardo and Moreno militia supported juntista or pro-independence conspiracies (Franco, 1977; Guardino, 1996: 49). Among the leaders of the latter plot was a member of the white elite, Luís Francisco Bassave who, according to the classic work of José Luciano Franco (1977: 5-6), sought the support of coloured inhabitants living in the poorer barrios of the city and even of the members of the free coloured militias. Among these was a Free Black named José Antonio Aponte, who two years later would lead a major insurrection of slaves and Free Blacks on the island (Barcia Zequeira, 2006: 251; Childs, 2006). In the region of Tierra Caliente (in south-western New Spain), many of the poor mulatto peasants participated in the revolutionary movement headed by the mestizo priest, José María Morelos, who enthusiastically encouraged the legislators to ban casta distinctions and to abolish slavery at the Congress of Chilpancingo in 1813 (Guardino, 1996: 44ss; Vincent, 1994: 259).

In Buenos Aires, the multi-coloured plebes (made up of Free Coloureds, Mestizos and also poor Whites) (Bernand, 2005: 147-148), after having greatly contributed to the defeat of the British invading forces in 1806 and 1807 , became important political actors both as members of the new militia corps, formed after those events, and by the pressure that they exerted in the streets. First, in 1809, against the will of the Cabildo, they opposed the deposition of French-born viceroy Santiago de Liniers (who had incorporated them into the militias during the mentioned invasions and authorized them to select their commanders). Secondly, they actively supported the pro-autonomy movement that eventually replaced the government of the province in 1810 . Hereafter, they continued to be politically active, often forcing important changes in the autonomous government or its policies. At times, they acted in coordination with white-Creole radicals who favoured socio-racial and political egalitarianism. These were mostly members of the political club called the Patriotic Society and, later on, of the Lautaro Lodge. This Masonic lodge had strong ties with its eponym lodge in Cádiz, and also with those founded in London by the tireless Venezuelan revolutionary, Francisco de Miranda. It took its name after a Mapuche chieftain, Rafael Lautaru, who had defeated and killed Chile's Conquistador, Pedro de Valdivia, in the $16^{\text {th }}$ century. This historic evocation reflects an important ideological feature of the revolutionaries of the early days, who often praised the pre-Columbian past and the brutality of the conquest to blame Spain of 300 years of colonial occupation, and thus justify independence (Di Meglio, 2011; Earle, 2007; Johnson, 2011).

It was the members of these white-Creole political factions who brought in the most radical measures in favour 
of the subaltern sectors in Buenos Aires, including the elimination of the Indian tribute, the granting of electoral rights to the multi-racial plebeians, the upgrading of the coloured militia battalions to the status of 'veterans' (id est, Spanish professional military units), and the previously referred-to free womb decree. During this time, the authorities would emancipate some slaves during the socalled Fiestas Mayas (held on each anniversary of the Revolution of May) and donations would be made to the widows of those who fell in the battlefields. Among the radicals, two former leaders of the failed 1809 Revolution of Chuquisaca (Alto Peru) stand out: Mariano Moreno, founder of the abovementioned Patriotic Society and who had vigorously advocated against the exploitation of Indians in the mines of Potosí; and Bernardo Monteagudo, who considered himself to be a 'frenetic republican' and was an enthusiastic supporter of the Rights of Men. In early 1812, Monteagudo published an article at the Gaceta de Buenos Aires (1911: 128) in which he argues that citizenship 'should not make the slightest difference between Europeans, Asians, Africans, and those born in America'. In spite of this and other enthusiastic declarations of universal equality, it seems that these white-Creole radicals were not entirely stripped of their socio-racial prejudices regarding the Afro-descendants. On June $14^{\text {th }} 1810$, the autonomous government of Buenos Aires made public an invitation to the Indian militiamen to join the white battalions and leave the casta units (mainly composed by Pardos and Morenos) ${ }^{8}$, as if it was "shameful" to be part of them.

In Central America and the northern territories of South America, the evocations to grant citizenship to Free Coloureds were more specific and their participation more decisive. In 1820, the Cabildo of Guatemala (which remained loyal to the Regency and the Crown) dispatched a deputy to the Cortes with instructions demanding the withdrawal of the 'ridiculous distinctions' established by the constitution of 1812 and which affected Afro-descendants. In 1821, after the independence of the United Provinces of Central America, for the election of members to its national congress it was agreed 'not to exclude from citizenship the natives from Africa' (Duran and Contreras, 1962: 226-227). In the provinces of Cartagena and Caracas, where political factions disagreed on the socio-racial scope of citizenship, the political collaboration between Free Coloureds and radical white-Creoles became crucial to attaining political equality. In November 1811, a coloured battalion (the Getsemaní Lancers), led by the Cubaborn pardo, Pedro Romero, in combination with some white-Creoles (in particular the Gutierrez de Piñeres brothers from the town of Mompox and Ignacio Muñoz from the town of Cozorla) and a multi-racial populace surrounded the building of the autonomous assembly, putting pressure on its members gathered inside to declare independence. The political participation of Free Coloureds during this period reached its peak on June 1812, when three Pardos (including Romero) that had been elected as legislators, signed the new constitution of the Independent State of Cartagena (Helg, 2004; Lasso, 2007).
In the case of Caracas, after the establishment of the autonomous government in April 1810, it became evident that most white representatives were no longer willing to go any further in granting political rights to Free Coloureds, than they were in approving a censitary citizenship. It was thanks to pressure exerted by members of what a foreign observer described as the 'mulatto party', that the general congress agreed to specifically ban, in the constitution sanctioned in December 1811, the socio-racial discrimination to which Pardos were subjected to. That radical faction was lead by Miranda himself, who had recently arrived from London. Although this revolutionary leader was not an advocate of general emancipation, he showed clear signs of being against the slave trade and the cruelties of modern slavery. He was above all a fervent defender of the Free Coloureds' right to citizenship, as evidenced by the republican projects he designed for Spanish America from 1801 onwards. Miranda profited from the great prestige he had and won the support of the more radical revolutionaries, most of them enlightened white-elite youngsters, like the Ribas brothers and the Bolivar brothers, with whom he founded the Patriotic Society. This political club became a public tribune in which, according to the testimony of a witness, its members spoke without restraint about 'equality and freedom among men' and whose doors were opened to people of 'all classes, statuses or conditions', including mulattoes, Free Blacks and probably even women. Notwithstanding this, it was not until the royalist armies were approaching Caracas in 1812, that Miranda took the decision to recruit a thousand slaves who would be emancipated after four years of military service (Gómez, 2008).

Much later, in the last third of the $19^{\text {th }}$ century, many Cuban revolutionaries also seemed determined to grant full citizenship to Free Coloureds, whose political equality has been guaranteed by the constitution of Guáimaro of 1869. The main white-Creole rebel leader, Carlos Manuel Céspedes, even named some of them as members of the cabildos of Báyamo and Jiguaní (Ferrer, 1999: 2242). Moreover, the revolutionary intellectual, José Martí, claimed in many of his texts the nonexistence of races and argued against any kind of race-thinking at all -a true "temerity" in a period in which Latin America was dominated by the positivist paradigm of progress and the doctrines of scientific racism. As with the early stages of the continental revolutions, those philanthropic gestures responded very much to the need to create a "raceless" national identity (Cubanidad) that could ensure the triumph of the republican cause. Other white Cuban patriots however were less candid in their assertions, arguing for instance that Blacks were indebted to them for having treated them "well" under slavery. Following Ada Ferrer, once independence was achieved the new republican authorities drifted away from Martís inclusive national ideals towards more contemporary forms of racial discrimination, corresponding both to the positivist notion of "civilisation" and to the ideal of "whiteness" of the U.S. occupiers (Ferrer, 1999: 187ss; Fuente, 2001: 24ss; Hatfield, 2010). 


\section{FEARSOME ATTITUDES}

From the perspective of the elites in the Americas, the long period of the revolutions is filled with "dangerous" examples of the damaging potential of the enlightened ideas and, more specifically, of radical republicanism. The Terror during the French Revolution, the collapse of Saint-Domingue during the Haitian revolution, and the most violent episodes of the wars of independence in Spanish America (such as the massacres of gachupines in New Spain and the 'terrible years' of the wars of independence in Venezuela) seemed to confirm those concerns. These "bad" examples, combined with the traditional concerns to servile wars and the racial prejudices of the white elites (to which belonged many of the leaders of the Spanish American revolutions), came to conform a particular 'climate of insecurity' — to use the expression of Jean Delumeau (1978) - that would affect the political attitudes of many major political figures of the period regarding socio-racial issues and towards the subaltern sectors. ${ }^{9}$

This emotional climate could occasionally affect the decisions of white leaders in stressful situations, as in the aforementioned case of Miranda's hesitation to emancipate slaves in 1812. This attitude responded very much to his fear of triggering anarchic revolutions, resulting from his traumatic experiences in France during the Terror and the knowledge he had of the revolution in Saint-Domingue. Shortly beforehand, he had discarded his previous more radical revolutionary projects and proposed instead a system of 'rational liberties', in which Jacobinism was rejected and emancipation denied to slaves. This Burkenian-inspired doctrine was shared by some of his collaborators such as Manuel Gual (one of the White Creoles implicated in the conspiracy of La Guaira of 1797) (Gómez, 2013: 195-196). Another of Miranda's collaborators, the New Grenadian Pedro Fermín de Vargas, in a memorandum he wrote in 1805 , shows his preoccupation with the danger posed by making offerings of freedom to slaves and Free Coloureds (Miranda, 1938: 277).

The Cuban revolutionary Joaquín Infante (one of the leaders of the Havana conspiracy of 1810) went even further in this direction: The notes he wrote during his stay in Caracas in 1811, about the autonomy project for the island of Cuba defended the maintenance of slavery on economic grounds and opposes the granting of political equality to the Free Coloureds, considering that it would be vain to believe in a permanent alliance between them and the Whites (Pichardo Viñals, 1965; Yacou, 2010: 565). Eventually, and for similar reasons, revolutionaries as radical as the formerly 'frenetic republican' Monteagudo, finished by becoming sceptical about the democratic potential of the republican system and the principle of popular sovereignty in a multi-racial society (Montoya, 2001: 93-105). Much later, José Martí and other white revolutionaries, albeit not sharing strictly the same frustrating sentiments, they still contemplated with certain anxiety the possible shift of their revolution into a race war, as may be seen in the Manifiesto de Montecristi of 1895. Hence, Aline Helg argues that the fears of race war continued to be present in the political thought of the leaders of Cuba Libre (Hatfield, 2010; Helg, 1995: 54), evidencing also the continuity of the emotional climate in question.

The massive military participation of subalterns in the local wars of independence, both in the royalist and the patriotic armies, and the political awareness they manifested in many places, greatly contributed to nourish the concerns of race war of the white leaders and even seemed to revitalize their traditional racial prejudices vis-à-vis the afro-descendants. In the case of Bolivar and other patriotic leaders, the war waged against the white-Creoles by the multi-coloured royalist army commanded by the chieftain José Tomás Boves in 1814, was particularly traumatic. According to John Lynch (2006), the risk of racial war persuaded Bolívar to become 'permanently committed to absolute abolition of slavery'. On the other hand, Bolivar did not show any particular sign of empathy towards the Free Coloureds, beyond the need of using them to reinforce the republican armies. In private, he seemed to consider them as dangerous people, who, if given too much political power, could eventually turn Greater Colombia into a 'pardocracy': a regime lead by coloured men or Pardos, as in Haiti (Helg, 2012, 2003: 447-471; Lynch, 2006: 290ss). In Cartagena de Indias, former member of the Patriotic Society of Caracas, Mariano Montilla, even criticized interracial marriages between white elite men and pardo women as a sign of 'dangerous republicanism' (Cf. Lasso, 2007: 118)

In Cuba, the incorporation of large numbers of slaves and Free Coloureds into the rebel army during the Ten Years' War, many of whom became important chieftains like the mulatto Antonio Maceo, worried the white leaders of the insurrection becoming thus one of the reasons to surrender through the Paz del Zanjón of 1878 (Ferrer, 1999: 22-42). The same concerns could have more dramatic consequences, as seen in the attitudes of Morelos in New Spain and Bolívar in Venezuela. Both leaders favoured the execution of the pardo chieftains Mariano Tabares in 1811 and Manuel Piar in 1817 respectively, arguing in similar terms and among other "sound" reasons that the intentions of the latter were to trigger race wars by encouraging hatred against the Whites (Hernández Jaimes, 2001: 167-172; Lynch, 1983: 15-16). In the following years, race war scares, mostly in the region of Cartagena de Indias, continued to motivate the arrest, banning and execution of Pardos (including elected authorities and high-ranking officers like Admiral José Prudencio Padilla) accused of conspiracy, even after the collapse of Greater Colombia in 1831 (Helg, 2003; Lasso, 2007: 129ss; Thibaud, 2011: 21-23).

The manifestations of the climate in question, may often take the form of seemingly philanthropic initiatives. The free-womb bill approved by the congress of the Republic of Antioquia in 1814 is particularly interesting in that regard. By that time, unlike other places in 
which similar measures were passed, slavery was still very important for the local economy. The author of the bill, José Félix Restrepo, counted with the decisive support of the chief-of-government, Juan del Corral, who shared his anti-slavery sentiments. Notwithstanding their will to put an end to slavery, behind their determination were their concerns about the potentially "harmful" impact of independence on the local slave population. The new local constitution, sanctioned in 1812, included a declaration of the universal rights of men. This led a group of around three hundred slaves from Medellín to make a plea before the local Cabildo, appealing for the recognition of their 'natural rights'. This petition aroused the concerns of the white political elite about fostering slave rebellions, the increasing of the Africanization of the territory or, "worse" still, triggering a Haitian-like revolution. ${ }^{10}$ According to María Eugenia Chaves, these concerns were a key factor behind the formulation of the free-womb law, not only in the case of Antioquia but also in that of Greater Colombia, as it was the same Restrepo who proposed the analogous bill approved by the Congress of Cucuta in 1821 (Chaves, 2011: 93). Similar motivations can be found behind the gradualist proposal included in the revolutionary manifesto drawn up by the white insurgents lead by Carlos Manuel Céspedes, at the outset of the Ten Years' War in Cuba in 1868 (Ferrer, 1999: 22).

The impact of Scientific Racism and, more specifically, of Social Darwinism contributed very much to the continuity and, in certain places, to the aggravation of the aforementioned climate. Even the Indians, whose image had been so much praised by the revolutionary ideology, were again downgraded this time to the status of 'racially inferior' and 'uncivilised savages' (Earle, 2007). Those doctrines inspired a new generation of white or whitened politicians, who brought in new policies to "improve" the race of local populations through European immigration, and even to justify genocide as seen in the Dessert campaigns in Argentina, the casta wars in Mexico (fought mainly in Yucatán and Sonora), and in the massacre of members of the Independent Coloured Party (PIC) in Cuba in 1912. This latter event may be considered as a direct consequence of the survival of the colonial social order after the independence of the island and, consequently, of the racial fears of the elites fuelled by the racialist doctrines introduced from the United States.

Although casta and other racial distinctions were officially banned by the governments of the young republics, the new "citizens of colour" continued to be discriminated in many sui-generis ways. As consequence, many members of the subaltern sectors felt attracted by the egalitarian rhetoric of the liberal parties, which they supported mainly by electoral and party politics. They could also embrace, or even lead, the several liberal rebellions that broke out throughout Latin America during the period. At times, the outbreak of socio-political turmoil and civil wars, or merely the rumours of such events, could trigger the alarms of race war as happened in Cartagena in the late 1820 s and in Venezuela in the midcentury (Andrews, 2004: 90-93; Lasso, 2007: 130; Zahler, 2013: 212, 219). In Cuba, in the first decades of the $20^{\text {th }}$ century, the rumours of Black political uprisings continued to frighten the white population. This permitted the survival of the traditional myth of the 'Black peril' and also the consolidation of the stereotype of the 'Black political agitator'. These and other elements were frequently evoked by the status quo to justify political discrimination of afro-descendants ensuring the white supremacy over the island and, at the same time, prove their capacity for self-government to U.S. occupiers (Ferrer, 1999: 192; Fuente, 2001; Séfil, 2010: 142-145).

\section{CONCLUSION}

As with other liberal politicians and revolutionaries in the Atlantic World, many of the political actions and ideas of those in Spain and Spanish America in favour of the subaltern sectors, derived mainly from the enlightened and liberal spirit of the time. They can also be tracked alongside the development of abolitionism and modern republicanism (in particular it's more radical doctrines like Jacobinism and Sans-culottism), and even by the socio-political consequences these doctrines had in different regions of Europe and the Americas. But those political actions and ideas also reflected more personal and cultural aspects (such as their life experiences, racial prejudices, religious beliefs and socio-political concerns) associated to the particular 'spaces of experience' - to use Reinhard Koselleck's theoretical formulation- ${ }^{11}$ where social actors lived and interacted with others. Thus, although they all shared a white/whitened or Spanish identity, the mentioned factors shaped, among other things, their socio-racial sensibilities and socio-political ideas in a way that would make them coincide — or not- with one another.

Accordingly, the historiography of the Spanish American independences has recently begun to stress the importance of the religious beliefs in the emergence of a sort of Catholic Republicanism. In spite of this, the religious convictions were seldom associated to the aim of granting political equality to subaltern sectors, with the exception of certain members of the Church as were Hidalgo and Morelos in New Spain, and probably Cañas in Central America. Others, with larger abolitionist backgrounds, did it more clearly - though not exclusivelybecause of their moral activism after their conversion to non-Catholic Christian churches, like Vizcarrondo and Blanco White. The fact of their conversion, and perhaps their experiences with Anglophone abolitionist groups, made them develop different sensibilities and aims from those of their countrymen. Thus, the engagement of Vizcarrondo may have contributed to finally give a movement structure to Spanish abolitionism in the 1860s. In the case of Blanco White, as it has been underlined by Schmidt-Nowara, he became the instrument for "spanishing" the ideas of British evangelical abolitionists and even sought to bring religious Reformation to South 
America (Corwin, 1967: 158-160; Schmidt-Nowara, 2013: 160-161).

The influence of abolitionism also helps to explain the immediacy of the proposals made against slave trade (in addition to British pressure), and the concurrent emergence of a gradualist thought in the Spanish Atlantic. Perhaps our Hispanic social actors shared the conviction that many British abolitionists had developed after the prohibition of the slave trade by Parliament in 1807, concerning the impossibility of carrying out a general emancipation of slaves until - as Wilberforce once remarked - they were 'more fit (...) to bear emancipation' (Cobbett, 1812: 146). This was also associated with the fears of fostering another Haitian-like revolution in the British West Indies, as a result of which the abolitionist question experienced a sort of stagnation in the United Kingdom in the years that followed that measure (Blackburn, 1988: 322).

The local socio-racial realities also played an important role in shaping the political convictions of the revolutionary leaders, as clearly seen in the cases of Caracas and Cartagena de Indias regarding the Pardos, and in the axis Chuquisaca-Buenos Aires regarding the Indians. Nonetheless, the pejorative remark made in Buenos Aires regarding the presence of Indians within the Casta battalions, the prejudiced attitudes some showed vis-à-vis the Pardos, and the reluctance to grant citizenship to afrodescendants at the Cortes of Cadiz, highlights the continuity of the colonial 'racial thinking' in many Spanish liberals and Spanish American revolutionaries. ${ }^{12}$ Moreover, although the white-Creole revolutionaries did agree to grant further political rights to the subaltern sectors (either voluntarily or because they were forced to do so), they nevertheless, distrusted and deeply feared their alleged predisposition towards anarchic revolutions. ${ }^{13} \mathrm{~A}$ similar concern was also responsible for the appearance - or the strengthening - of the fear of 'Africanization' in Antioquia and of Bolivar's concern against the emergence of 'pardocracies'; albeit, in both cases, the traditional prejudices seemed to have played an important role.

In Cuba, it was the will of the Cuban elites to carry out a different liberal "revolution", intending to turn the island into a plantation colony, which from its very outset — as can be seen in Arango's original project of 1792feared the increment of the coloured population and so they proposed to increase white immigration. It was not until they foresaw that project becoming a reality in the 1820 s that Father Varela and his intellectual pupils decided to take action against the slave trade and the perpetuation of slavery. Unlike other territories in Spanish America, the manipulation of the 'Black Peril' by the authorities - first colonial and then republican - and the continuation of the structural elements that nourished the race scares (slave rebellions, socio-political unrest and the massive presence of afro-descendants) will make them last way into the $20^{\text {th }}$ century.

Finally, notwithstanding this myriad of prejudiced and fearful attitudes towards the afro-descendants ex- pressed by our social actors, the events and debates that transpired in the provinces of Caracas and Cartagena de Indias during the revolutions which led to their independences, the political upheavals in Cuba, Tierra Caliente and other regions of Spanish America, and even the partial enfranchisement of Afro-descendants carried out by the Cortes of Cádiz - considered by Jaime Rodriguez (2008) as a major political breakthrough when compared to other cultural regions-, can be considered, after the Mulatto Affaire in France in the early 1790 s, as a second golden moment in the struggles for granting political equality to subaltern sectors in the Atlantic World.

The research for this article was partially funded by the project: Cultures of Cabotage: French, British and Spanish Antilles, (1650-1800), HAR2012-37455-C03-03. It is dedicated to the memory of my friend and colleague, Christopher Schmidt-Nowara.

\section{NOTES}

1 The influential works of François-Xavier Guerra (1992) considers that the Spanish American independences began only after the outset of the crisis of the Spanish Monarchy in 1808 and underestimate the participation of subaltern sectors in the processes of Independence.

2 On the subject of the plebeians in Latin America, see the especial issue of the journal Caravelle $(8,1988)$, entitled "Plèbes urbaines en Amérique latine".

3 It is worth mentioning that, by that time, Villavicencio maintained correspondence on the subject with José Félix Restrepo from Antioquia, who would become one of the most enthusiastic supporters of this sort of measure in Greater Colombia (Bierck, 1953: 26; Blanchard, 2008: 22; Ricaurte, 2002: 165166; Romero Jaramillo, 2003).

4 Although this conspiracy has been underestimated by Chilean historiography whose representatives qualify it as naive, it is still the very first modern attempt to abolish slavery within the Spanish Atlantic.

5 On the impact of the revolution in Guadeloupe on the Spanish mainland, see: Gómez (2006) and Pérotin-Dumon (1989).

6 It is interesting to note that Schœlcher began to develop antislavery sentiments after visiting Cuba in 1830 (Garrison, 1979: 566; Special report of the Anti-slavery conference, held in Paris, Aug. 1867, 1869).

7 With the exception of Caracas, the other cases have not yet been studied in enough depth (Almarza, 2010; Gómez, 2008).

8 General Belgrano issued a proclamation in the same vein at his arrival to the province of Misiones. $C f$. Seghesso de López (2010: 18-22).

9 For a more transnational perspective of this emotive phenomenon, see: Alejandro E. Gómez (2013: 185ss).

10 There was a similar petition by some slaves in Guatemala in 1823; it did not produce the same dramatic effect as in Antioquia surely because the slaves had remained calm and were not so numerous as in the former territory (Duran and Contreras, 1962: 228).

11 According to Reinhard Koselleck, an individual's experiences can affect their expectations and, consequently, their attitudes towards certain situations or realities (Koselleck, 1985).

12 Here we follow the notion of 'race thinking' defined by Irene Silverblatt (2004: 17-18).

13 That distrust has been noticed by many researchers in different contexts throughout Spanish America during the revolutions. See for instance: Di Meglio (2006); Fradkin (2008); Gómez (2008); Guardino (1996); Hamnett (1986); Helg (2004); and Lasso (2007) 


\section{REFERENCES}

Acebrón, María Dolores Domingo (1998) "Rafael María de Labra ante la cuestión de Cuba, 1898". Anuario de estudios americanos, 55(1): 153-164.

Almarza, Angel R. (2010) "El movimiento juntista de 1810 en la Capitanía General de Venezuela". Historia Caribe, 16: 31-52.

Almeida, Joselyn M. (2011) Reimagining the Transatlantic, 17801890. Ashgate Publishing, Farnham, Burlington.

Alonso, Angela (2010) "O abolicionista cosmopolita: Joaquim Nabuco e a rede abolicionista transnacional". Novos Estudios, 88: 55-70.

Andrews, George Reid (1980) The Afro-Argentines of Buenos Aires, 1800-1900. University of Wisconsin Press, Madison.

Andrews, George Reid (2004) Afro-Latin America, 1800-2000. Oxford University Press, New York.

Arroyo Jiménez, Paloma (1982) "La sociedad abolicionista Española, 1864-1886". Cuadernos de Historia Moderna y Contemporánea, 3: 127-149.

Barcia Zequeira, María del Carmen (2006) "Des bataillons de pardos et de morenos à Cuba (1600-1868)". In D'esclaves à soldats: miliciens et soldats d'origine servile, XIIIe-XXIe siècles, edited by Carmen Bernand and Alessandro Stella. L'Harmattan. Paris: 245-264

Bénot, Yves (1988) La révolution française et la fin des colonies: Essai. La Découverte, Paris.

Bernand, Carmen (2005) "La plèbe ou le peuple? Buenos Aires, fin XVIIIe-début xixe siècle". Caravelle, 84: 147-168.

Berquist, Emily (2010) "Early Anti-Slavery Sentiment in the Spanish Atlantic World, 1765-1817." Slavery \& Abolition, 31(2): 181-205.

Bierck, Harold (1953) "The Struggle for Abolition in Gran Colombia." The Hispanic American Historical Review, 33(3): 365386.

Blackburn, Robin (1988) The Overthrow of Colonial Slavery, 17761848. Verso, London.

Blanchard, Peter (1992) Slavery \& abolition in early republican Peru. SR Books, Wilmington.

Blanchard, Peter (2008) Under the flags of freedom: slave soldiers and the wars of independence in Spanish South America. University of Pittsburgh Press, Pittsburgh.

Boidin, Capucine (2006) "Esclaves, pardos et milices au Paraguay (xvire-XIxe siècles)". In D'esclaves à soldats: miliciens et soldats d'origine servile, xiiie-xxie siècles, edited by Carmen Bernand and Alessandro Stella. L'Harmattan. Paris: 329-352.

Bolívar, Simón (1939) Proclamas y discursos del Libertador. Litografía y Tipografía del Comercio, Caracas.

Brading, David (1984) Prophecy and Myth in Mexican History. Centre of Latin American Studies, Cambridge.

Brown, Christopher Leslie (2006) Moral capital: foundations of British abolitionism. University of North Carolina Press, Chapel Hill.

Chaves, María Eugenia (2011) "Esclavos, libertades y república. Tesis sobre la polisemia de la libertad en la primera república antioqueña”. EIAL: Estudios Interdisciplinarios de America Latina y el Caribe, 22(1): 81-104.

Childs, Matt D. (2006) The 1812 Aponte Rebellion in Cuba and the Struggle Against Atlantic Slavery. The University of North Carolina Press, Chapel Hill.

Clementi, Hebe (1974) La abolición de la esclavitud en América Latina. La Pléyade, Buenos Aires.

Cobbett, William (1812) Cobbett's Parliamentary Debates, during the second session of the second parliament of the United Kingdom of Great Britain and Ireland, and of the Kingdom of Great Britain the Nineteen. Vol. VIII. R. Bagshaw, London.

Contreras Cruces, Hugo (2011) "Artesanos mulatos y soldados beneméritos: El Batallón de Infantes de la Patria en la Guerra de Independencia de Chile, 1795-1820". Historia, 44(1): 51-89.

Cooney, Jerry W. (1974) "Abolition in the Republic of Paraguay: 1840-1870". Jahrbuch für Geschichte Lateinamerikas, XI: 149166.
Corwin, Arthur F. (1967) Spain and the Abolition of Slavery in Cuba, 1817-1886. University of Texas Press, Austin.

Davis, David Brion (1988) The Problem of Slavery in Western Culture. Oxford University Press, New York.

Delumeau, Jean (1978) La peur en Occident, XIVe-XVIIIe siècles: une cité assiégée. Fayard, Paris.

Dérozier, Albert (1978) Manuel José Quintana y el nacimiento del liberalismo en España. Ediciones Turner, Madrid.

Diario de las discusiones y actas de las cortes (1811). Vol. III. Imprenta Real, Cadiz.

Diario de las discusiones y actas de las cortes (1811). Vol. IV. Imprenta Real, Cadiz.

Díaz Soler, Luis M. (1970) Historia de la esclavitud negra en Puerto Rico. Universidad de Puerto Rico, San Juan.

Di Meglio, Gabriel (2006) Viva El Bajo Pueblo!: La Plebe Urbana De Buenos Aires y la política entre la revolución de mayo y el rosismo (1810-1829). Prometeo Libros, Buenos Aires.

Di Meglio, Gabriel (2011) "La participación popular en la revolución de independencia en el actual territorio argentino, 18101821". Anuario de Estudios Americanos, 68(2): 429-454.

Domingo Acebrón, María Dolores (2006) Rafael María de Labra: Cuba, Puerto Rico, Las Filipinas, Europa y Marruecos, en la España del sexenio democrático y la Restauración (18711918). CSIC, Madrid.

Drescher, Seymour (2009) Abolition: a history of slavery and antislavery. Cambridge University Press, Cambridge, New York.

Dubois, Laurent (2004) A Colony of Citizens: Revolution \& Slave Emancipation in the French Caribbean, 1787-1804. University of North Carolina Press, Chapel Hill.

Duran, Carlos Martinez, and Contreras, Daniel (1962) "La abolicion de la esclavitud en Centroamérica". Journal of Inter-American Studies, 4(2): 223-232.

Dym, Jordana (2006) From Sovereign Villages to National States: City, State, and Federation in Central America, 1759-1839. University of New Mexico Press, Albuquerque.

Earle, Rebecca (2007) The Return of the Native: Indians and MythMaking in Spanish America, 1810-1930. Duke University Press, Durham.

Ehrard, Jean (1995) "L'esclavage devant la conscience morale des limières françaises: indifférence, gêne, révolte". In Les abolitions de l'esclavage: de L.F. Sonthonax à V. Schoelcher, 1793, 1794, 1848, edited by Marcel Dorigny. Presses universitaires de Vincennes; UNESCO, Saint-Denis: 143-152.

Feliú Cruz, Guillermo (1973) La abolición de la esclavitud en Chile; estudio histórico y social. Editorial Universitaria, Santiago de Chile.

Ferrer, Ada (1999) Insurgent Cuba : race, nation, and revolution, 1868-1898. University of North Carolina Press, Chapel Hill; London.

Fradkin, Raúl (ed.) (2008) ¿Y el pueblo dónde está?: Contribuciones para una historia popular de la revolución de independencia en el Río de la Plata. Prometeo Libros, Buenos Aires.

Franco, José Luciano (1977) Las conspiraciones de 1810 y 1812. Editorial de Ciencias Sociales, La Habana.

Fuente, Alejandro de la (2001) A Nation for All: Race, Inequality, and Politics in Twentieth-century Cuba. University of North Carolina Press, Chapel Hill

Gaceta de Buenos Aires (1810-1821) (1911). Vol.1. Compañía SudAmericana de Billetes de Banco, Buenos Aires.

Gallego, José Andrés (2005) La esclavitud en la América española. Encuentro, Madrid.

Garrigus, John (2011) "Vincent Ogé Jeune (1757-1791): Social Class and Free Colored Mobilization on the Eve of the Haitian Revolution." The Americas, 68 (1): 33-62.

Garrison, William Lloyd (1979) The Letters of William Lloyd Garrison: Let the Oppressed Go Free, 1861-1867. Harvard University Press, Cambridge.

Ghorbal, Karim (2009) Réformisme et esclavage à Cuba. Publibook Université, Paris.

Goldman, Noemí (2009) "La Revolución de Mayo: Moreno, Castelli y Monteagudo. Sus discursos políticos". Revista Ciencia y Cultura, 22-23: 321-351. 
Gómez, Alejandro E. (2005a) “Ciudadanos de color? El problema de la ciudadanía de los esclavos y Gente de Color durante las revoluciones franco-antillanas, 1788-1804". Anuario de Estudios Bolivarianos, XI (5): 117-158.

Gómez, Alejandro E. (2005b) "El estigma africano en los mundos hispano-atlánticos (Siglos XIV al XIX)". Revista de História, 153: $139-179$.

Gómez, Alejandro E. (2006) "Entre résistance, piraterie et républicanisme: mouvements insurrectionnels d'inspiration révolutionnaire franco-antillaise dans la Côte de Caracas, 1794-1800". Travaux et Recherches de l'UMLV, (11): 91-120.

Gómez, Alejandro E. (2008) "La Revolución de Caracas desde abajo. Impensando la primera independencia de Venezuela desde la perspectiva de los Libres de Color, y de las pugnas políticobélicas que se dieran en torno a su acceso a la ciudadanía, 17931815". Nuevo Mundo-Mundos Nuevos, 8. doi: 10.4000/nuevomundo.32982 [accesed 01/May/2015]

Gómez, Alejandro E. (2013) Le spectre de la révolution noire: l'impact de la révolution haïtienne dans le monde atlantique. Presses Universitaires de Rennes, Rennes.

Grases, Pedro (1997) La conspiración de Gual y España y el ideario de la independencia. Academia Nacional de la Historia, Caracas.

Guardino, Peter F. (1996) Peasants, Politics, and the Formation of Mexico's National State: Guerrero, 1800-1857. Stanford University Press, Stanford.

Guédez, José Marcial Ramos, and Mendoza, Irma (2000) “José Silverio González y la abolición de la esclavitud en Venezuela, 1850-1854". Boletín de la Academia Nacional de la Historia, 83 (332): 342-366.

Guerra, François-Xavier (1992) Modernidad e independencias. MAPFRE, Madrid.

Halperín Donghi, Tulio (1972) Revolución y guerra: formación de una élite dirigente en la Argentina criolla. Siglo XXI, Buenos Aires.

Hamnett, Brian R. (1986) Roots of Insurgency: Mexican Regions, 1750-1824. Cambridge University Press, Cambridge.

Hatfield, Charles (2010) "The Limits of «Nuestra América»". Revista hispánica moderna, 63 (2): 193-202.

Helg, Aline (1995) Our rightful share : the Afro-Cuban struggle for equality, 1886-1912. University of North Carolina Press, Chapel Hill.

Helg, Aline (2003) "Simon Bolivar and the spectre of pardocracia: Jose Padilla in post-independence Cartagena." Journal of Latin American Studies, 35: 447-471.

Helg, Aline (2004) Liberty and Equality in Caribbean Colombia, 1770-1835. University of North Carolina Press, Chapel Hill.

Helg, Aline (2012) Simón Bolívar's Republic: a bulwark against the «Tyranny» of the Majority. Revista de Sociologia e Politica, 20 (42): 21-37.

Hernández Jaimes, Jesús (2001) "Cuando los mulatos quisieron mandar". In Los sentimientos de la nación. Entre la espada espiritual y militar y los orígenes del Estado de Guerrero, edited by José Gilberto Garza and Tomás Bustamante. Editorial Laguna, Mexico: 141-173.

Herreión Peredo, Carlos (2011) "La abolición de la esclavitud en Miguel Hidalgo". Letras Históricas, 5: 39-52.

Johnson, Lyman (2011) Workshop of Revolution: Plebeian Buenos Aires and the Atlantic World, 1776-1810. Duke University Press, Durham.

Kerson, Arnold (1995) "Francisco Javier Alegre, humanista mexicano del siglo xvIII, y la esclavitud". In Actas del XII Congreso de la Asociación Internacional de Hispanistas, edited by Trevor Dadson, Vol. VI. University of Birmingham, Birmingham: 308313.

King, James (1953) "The Colored Castes and American Representation in the Cortes of Cadiz." The Hispanic American Historical Review, 33 (1): 33-64.

Koselleck, Reinhart (1985) Futures past: on the semantics of historical time, Keith Tribe (trad.). Columbia University Press, New York.
Lasso, Marixa (2007) Myths of Harmony: Race and Republicanism during the Age of Revolution, Colombia, 1795-1831. University of Pittsburgh Press, Pittsburgh.

Lasso, Marixa (2013) "Los grupos afro-descendientes y la independencia: ¿un nuevo paradigma historiográfico?” In L'Atlantique révolutionnaire: une perspective ibéro-américaine, edited by Gabriel Entin et al. Les Perséides, Rennes: 359-378.

León, Leonardo (2002) "Reclutas forzados y desertores de la patria: el bajo pueblo chileno en la guerra de la independencia, 18101814". Historia, 35: 251-297.

Llano, Alonso V. (1992) "Elites, burocracia, clero y sectores populares en la independencia quiteña (1809-1812)". Procesos, Revista Ecuatoriana de Historia, 3: 55-101.

Lombardi, John V. (1971) The decline and abolition of Negro slavery in Venezuela, 1820-1854. Greenwood Publishing, Westport.

López García, José Tomás (1982) Dos defensores de los esclavos negros en el siglo XVII, Francisco José de Jaca y Epifanio de Moirans. Corpozulia; Universidad Católica Andrés Bello, Maracaibo, Caracas.

Lynch, John (1973) The Spanish American Revolutions, 1808-1826. Norton, New York.

Lynch, John (1983) "Bolivar and the Caudillos." The Hispanic American Historical Review, 63 (1): 3-35.

Lynch, John (2006) Simón Bolivar: A Life. Yale University Press, New Haven.

Martínez, Ana María Argüello (1999) El rol de los esclavos negros en el Paraguay. Paraguayo S.R.L., Asunción.

Mascaraque, Belén Pozuelo (1988) "Sociedad española y abolicionismo en la segunda mitad del siglo XIX". Cuadernos de historia contemporánea, 10: 71-92.

Mathews, Thomas G. (1971) "La visita de Víctor Schoelcher a Puerto Rico". Revista del Instituto de Cultura Puertorriqueña, 14 (50): 21-24.

Miranda, Francisco de (1938) Archivo del General Miranda, vol. XXI. Tipografía Americana, Caracas.

Montoya, G. (2001) "Pensamiento político de Bernardo Monteagudo: entre el autoritarismo y la democracia”. Investigaciones Sociales, V (8): 81-111.

Morales Carrión, Arturo (1986) "Ojeada a las corrientes abolicionistas en Puerto Rico". Anuario de Estudios Hispanoamericanos, 43: 295-309.

Moreno García, Julia (2003) "La cuestión de la trata en el Trienio Liberal (1820-1823)". Cuadernos de historia contemporánea, extra (1): 157-167.

Múnera, Alfonso (1998) El fracaso de la nación: región, clase y raza en el Caribe colombiano (1717-1821). Ancora Editores, Bogotá.

Murray, David R. (2002) Odious Commerce: Britain, Spain and the Abolition of the Cuban Slave Trade. Cambridge University Press, Cambridge.

Naranjo Orovio, Consuelo y Armando García González (1996) Racismo e inmigración en Cuba en el siglo XIX. Doce Calles, Madrid.

Paquette, Robert L. (1988) Sugar Is Made with Blood: The Conspiracy of La Escalera and the Conflict Between Empires Over Slavery in Cuba. Wesleyan University Press, Middletown.

Pérotin-Dumon, Anne (1989) "Révolutionnaires Français et Royalistes Espagnols dans les Antilles". Revue Française d'Histoire d'Outre-Mer, LXXVI (282-283): 126-158.

Pichardo Viñals, Hortensia (1965) Documentos para la historia de Cuba, vol. I. Editorial Nacional de Cuba, Editora del Consejo Nacional de Universidades, La Habana.

Piqueras Arenas, José A. (2007) Félix Varela y la prosperidad de la patria criolla. Fundación MAPFRE, Doce Calles, Madrid.

Pons, André (1997) "Blanco White, abolicionista". Cuadernos hispanoamericanos, 559: 63-76.

Ricaurte, Carmen Ortega (2002) Negros, mulatos y zambos en Santafé de Bogotá: sucesos, personajes y anécdotas. Academia Colombiana de Historia, Bogotá.

Rieu-Millán, Marie Laure (1990) Los diputados americanos en las Cortes de Cádiz. CSIC, Madrid.

Rodriguez, Jaime E. (2008) "«Equality! The sacred right of Equality»: representation under constitution of 1812". Revista de Indias, 68 (242): 97-122. 
Romero Jaramillo, Dolcey (2003) El fantasma de la revolución haitiana. Esclavitud y libertad en Cartagena de Indias, 1812-1815. Historia Caribe, 3 (8): 19-33.

Schmidt-Nowara, Christopher (1999) Empire and Antislavery: Spain, Cuba and Puerto Rico, 1833-1874. University of Pittsburgh Press, Pittsburgh.

Schmidt-Nowara, Christopher (2011) Slavery, freedom, and abolition in Latin America and the Atlantic world. University of New Mexico Press, Albuquerque.

Schmidt-Nowara, Christopher (2013) "Wilberforce Spanished: Joseph Blanco White." In Slavery and Antislavery in Spain's Atlantic Empire, edited by Josep M. Fradera and Christopher Schmidt-Nowara. Berghahn Books, New York: 158-175.

Scott, Rebecca J. (1985) Slave Emancipation in Cuba: The Transition to Free Labor, 1860-1899. University of Pittsburgh Press, Pittsburgh.

Séfil, Marc (2010) Les Noirs à Cuba au début du xxe siècle 18981933: Marginalisation et lutte pour l'égalité. Editions L'Harmattan, Paris.

Seghesso de López, M. Cristina (2010) "La Revolución de Mayo y los indígenas. Vivencias y políticas vindicatorias". Revista de historia del derecho, 39: 1-34.

Silverblatt, Irene Marsha (2004) Modern Inquisitions: Peru and the colonial origins of the civilized world. Duke University Press, Durham.

Solano, Francisco de, and Guimerá Ravina, Agustín (eds.) (1990) Esclavitud y derechos humanos: la lucha por la libertad del negro en el siglo xix. CSIC, Madrid.

Special report of the Anti-slavery conference, held in Paris, Aug. 1867 (1869). Committee of the British and Foreign Anti-Slavery Society, London.

Távara, Santiago (1855) Abolición de la esclavitud en el Perú. Imprenta del Comercio, Lima.

Thibaud, Clément (2003) Repúblicas en armas : los ejércitos bolivarianos en la guerra de Independencia en Colombia y Venezuela. Instituto Francés de Estudios Andinos; Planeta, Lima; Bogotá.
Thibaud, Clement (2011) "La ley y la sangre: la «guerra de razas» y la Constitución en la América bolivariana”. Almanack, 1: 5-23.

Toral, André (2007) "La participación de los negros esclavos en la guerra del Paraguay". In Les guerres du Paraguay aux 19 et 20 siècles, edited by Nicolas Richard, Luc Capdevila, and Capucine Boidin. CoLibris, Paris: 418-428.

Tornero, Pablo (2005) "Azúcar, esclavitud y racismo: oligarquía criolla y colonialismo en Cuba". Cahiers du monde hispanique et luso-brésilien, 85: 31-48.

Vilar, Enriqueta Vila (1977) "La esclavitud americana en la política española del siglo XIX". Anuario de estudios americanos, 34: 563-588.

Vilar, Enriqueta Vila (1986) "Intelectuales españoles ante el problema esclavista". Anuario de estudios americanos, 43: 201-214.

Vilar, Enriqueta Vila (2006) "Crisis colonial y abolicionismo". In La excepción americana: Cuba en el ocaso del imperio coloni$a l$, edited by José A. Piqueras Arenas and Imilcy Balboa Navarro. UNED Alzira-Valencia; Fundación Instituto de Historia Social, Valencia: $239-252$

Vincent, Ted (1994) "The Blacks Who Freed Mexico." The Journal of Negro History, 79(3): 257-276.

Vincent, Theodore G. (2001) The legacy of Vicente Guerrero: Mexico's first Black Indian president. University Press of Florida, Gainesville.

Wanquet, Claude (1998) La France et la première abolition de l'esclavage, 1794-1802: le cas des colonies orientales, Ile de France (Maurice) et la Réunion. Karthala, Paris.

Wilberforce, William (1841) The Correspondence of William Wilberforce. H. Perkins, Philadelphia.

Yacou, Alain (2010) Essor des plantations et subversion antiesclavagiste à Cuba, 1791-1845. Karthala; CERC, Université des Antilles et de la Guyane, Paris, Pointe-à-Pitre.

Zahler, Reuben (2013) Ambitious rebels: remaking honor, law, and liberalism in Venezuela, 1780-1850. The University of Arizona Press, Tucson. 